JPPMS, Vol. 4, No. 1, 2020

Jurnal Penelitian Pendidikan Matematika dan Sains

http://journal.unesa.ac.id/index.php/jppms/

\title{
Pengaruh Musik Pop Terhadap Hasil Belajar Siswa SMA Kelas XI Pada Topik Barisan Dan Deret
}

\author{
Oleh: \\ Auliaul Haque1, Ika Kurnia sari, ${ }^{2}$, Siti M Amin ${ }^{3}$ \\ 1,2,3 Jurusan Matematika FMIPA Universitas Negeri Surabaya \\ 1auliaulhaque16030174053@mhs.unesa.ac.id \\ 2ikakurniasari@unesa.ac.id \\ ${ }^{3}$ sitiamin@unesa.ac.id
}

\begin{abstract}
Abstrak - Pada penelitian ini memiliki tujuan untuk mengetahui apakah musik pop berpengaruh signifikan terhadap hasil belajar matematika pada siswa SMA. Penelitian ini dilakukan pada siswa Kelas XI SMAN 1 Pamekasan semester Genap Tahun Pelajaran 2019/2020 pada materi aplikasi barisan dan deret. Jenis penelitian ini berupa eskperimen dengan rancangan penelitian Post-test Only Control Design. Teknik pengumpulan data yang gunakan adalah post-test berupa tes hasil belajar dengan lima soal uraian. Kelas eksperimen dan kelas kontrol diuji homogenitas terlebih dahulu menggunakan data nilai ulangan sebelumnya. Kemudian diperoleh bahwa kedua kelas homogen. Pada perhitungan nilai post-test dengan SPSS diketahui bahwa nilai sinignifikansi $<\alpha$ yaitu sebesar 0,047 sedangkan nilai $\alpha=0,05$, yang menandakan bahwa musik pop berpengaruh signifikan terhadap hasil belajar. Hasil belajar siswa yang diperoleh, menunjukkan adanya perbedaan yang signifikan pada kelas eksperimen dan kelas kontrol. Kelas eksperimen memiliki rata-rata hasil belajar yang lebih tinggi yaitu sebesar 84,61 daripada kelas kontrol yaitu sebesar 76,16. Berdasarkan data hasil penelitian, dapat disimpulkan bahwa musik pop berpengaruh secara positif terhadap hasil belajar matematika siswa sehingga dapat digunakan sebagai alternatif strategi pembelajaran.
\end{abstract}

Kata kunci: Musik Pop, Hasil Belajar Siswa, Barisan dan Deret

\begin{abstract}
This study aims to determine whether pop music has an effect on mathematic's student learning outcomes. This research was conducted of Class XI at SMAN 1 pamekasan of sequence and series aplication matter. This research was experimental research with a Post-test Only Control Design. The technique to collect data used a post-test that consisting of five descriptive questions. The experimental class and the control class were homogenity tested first using the previous test data. Then it is obtained that both classes are homogeneous. In the calculation of the post-test value with SPSS, it is known that the significance value $<\alpha$ is 0.047 while the value of $\alpha=0.05$, which indicates that pop music has a significant effect on learning outcomes. There are differences in significant learning outcomes in the experimental class and the control class. The experimental class had a higher average learning outcome of 84.61 than the average of the control class of 76.16. Based on research data, it can be concluded that pop music has a positive effect on student mathematics learning outcomes so it can be used as an alternative learning strategy.
\end{abstract}

Keywords: Pop Music, Learning Outcomes, Sequence and Serie

\section{Pendahuluan}

Musik telah menjadi pendamping di hampir setiap kegiatan manusia. Setiap kalangan masyarakat suka mendengarkan musik. Anak-anak hingga orang dewasa suka mendengarkan musik. Seseorang yang melakukan kegiatan sambil mendengarkan musik akan membuat kegiatan yang dilakukan tersasa menyenangkan. Musik juga sangat cocok didengarkan pada saat waktu luang.

Musik terdiri atas tiga aspek, yakni: melodi, irama, dan harmoni (Grimonia, 2014). Melodi merupakan suatu frekuensi yang bergetar dengan teratur sehingga menjadi bagian penting pada suatu komposisi musik. Harmoni berasal dari melodi yang dimainkan bersamaan. Pola teratur yang menjadikan sebuah komposisi enak dinikmati disebut irama. Ukuran kecepatan irama pada musik disebut tempo dengan notasi beat per minute (bpm). Tempo musik dibagi menjadi tiga yaitu lambat (40-69 bpm), sedang (70-99 bpm) dan cepat (100-208 bpm). Melodi, irama, dan harmoni berpengaruh pada manusia. Menurut Grimonia 
(2014) melodi mempengaruhi tubuh, irama memengaruhi emosi, dan harmoni memengaruhi jiwa.

Musik memiliki bermacam-macam genre yaitu rock, pop, jazz, dangdut, dan klasik. Menurut Taher (2009), setiap genre musik memiliki karakteristik yang berbeda-beda. Misalnya musik jazz dominan terhadap instrumental musik sedangkan musik rock dominan terhadap lirik lagu. Musik dangdut sangat khas dengan suara gendangnya. Sementara musik pop biasanya berbentuk lagu sederhana dan terdapat bagian yang diulang-ulang.

Musik pop sangat digemari oleh kalangan remaja Indonesia (Silalahi, 2017). Nielsen Radio Measurement melakukan survei terhadap 8400 orang di 11 kota di Indonesia tahun 2017 yang menunjukkan bahwa sebanyak $57 \%$ remaja Indonesia menyukai musik pop. Hasil survey tersebut sesuai dengan tangga lagu di aplikasi musik Spotify dan Joox menunjukkan lagu bergenre pop menduduki posisi atas. Pop sendiri berasal dari kata "populer". Genre musik ini mudah diterima di masyarakat karena sederhana dan nada yang digunakan mudah diingat. Musik pop sering kali dimainkan pada tempat-tempat umum untuk didengarkan masyarakat.

Musik dengan bermacam-macam genre telah digunakan pada pembelajaran terutama musik klasik. Musik klasik dipercaya dapat meningkatkan konsentrasi. Namun, penelitian yang dilakukan oleh Chou (2010) dan Salim (2010) mengungkapkan musik klasik justru mengganggu konsentrasi siswa. Musik yang diputar memiliki nada terlalu pelan.

Berbeda dengan musik klasik, musik pop memiliki nada yang lebih sederhana. Menurut Taher (2009) kesederhanaan musik pop menyebabkan masyarakat lebih menyukai musik pop. Musik pop disukai karena memiliki irama yang tidak terlalu cepat dan tidak terlalu pelan. Menurut Grimonia (2014) musik yang memiliki irama kuat dapat meningkatkan konsentrasi sedangkan musik yang memiliki irama lambat dapat meningkatkan fokus. Matematika merupakan mata pelajaran yang membutuhkan konsentrasi dan fokus.

Matematika merupakan ilmu pengetahuan yang sangat dibutuhkan dalam kehidupan sehari-hari. Semua kegiatan kita, sering kali menggunakan matematika. Namun, di Indonesia nilai UN matematika siswa masih rendah. Hal tersebut ditinjau dari data nilai UN matematika, menurut Kemendikbud (2019) pada siswa SMA jurusan IPA di tahun 2019 sebesar 39,37. Nilai tersebut menurun jika dibandingkan pada tahun 2018 yakni sebesar 39,61, Data tersebut menunjukkan bahwa hasil belajar siswa di Indonesia pada pelajaran matematika menurun.

Hasil belajar merupakan perubahan tingkah laku yang dialami oleh siswa melalui kegiatan belajar mengajar (Prasetya, 2012). Hasil belajar diperlukan untuk mengetahui sejauh mana siswa telah belajar. Menurut Moore (dalam Ricardo 2017) hasil belajar memiliki tiga aspek diantaranya afektif, psikomotorik, dan kognitif. Aspek-aspek tersebut tetap ada pada hasil belajar matematika namun yang dinilai paling utama adalah aspek kognitif. Pembelajaran matematika pada SD, SMP, dan SMA lebih menekankan pada peningkatan kemampuan siswa dalam aspek kognitif (Selverius, 1999).

Hasil belajar matematika yang rendah dipengaruhi beberapa faktor salah satunya ketidaknyamanan siswa dalam belajar matematika. Siswa mengalami stress dan jenuh saat belajar matematika (Aritonang, 2008). Siswa menganggap matematika sulit sehingga terdapat tekanan pada diri sendiri. Tekanan yang berlebihan membuat siswa semakin stress sehingga siswa kurang fokus dan konsentrasi.

Pada pembelajaran matematika, Siswa SMA di Pamekasan mengalami kesulitan pada materi barisan dan deret, khususnya materi aplikasi Barisan dan Deret Geometri. Daya serap siswa SMA di Pamekasan pada materi aplikasi Barisan dan Deret tergolong rendah yaitu sebesar 44,13\% (Kemendikbud, 2019). Hal tersebut masih cukup jauh dari harapan yakni sebesar 55\%. Materi barisan dan deret merupakan materi yang membutuhkan ketelitian. Menurut Sumargiyani (2018) pada materi barisan dan deret, siswa telah mengetahui langkah-langah menyelesaikan soal. Kesulitan siswa yang ditemukan adalah siswa sering salah dalam prosedur pengerjaan soal karena kurang teliti dan konsentrasi. Oleh karna itu, perlu adanya usaha untuk meningkatkan fokus dan konsentrasi siswa salah satunya dengan diperdengarkan musik pop. Menurut Natalia (2017) musik dapat menstimulasi kerja otak sehingga meningkatkan konsentrasi dan fokus seseorang.

Beberapa penelitian terdahulu mengungkapkan bahwa musik memiliki pengaruh yang besar. Menurut Rosidah (2012) mengungkapkan musik pop memiliki efek yang lebih tinggi dari pada musik klasik. Siswa yang mendengarkan musik pop mengalami peningkatan kinerja pada tes matematika sebesar $46,22 \%$ sedangkan pada siswa yang mendengarkan musik klasik mengalami peningkatan sebesar 25,39\%. Menurut Pramudhita (2019) mengungkapkan siswa yang mempunyai kebiasaan mendengarkan musik saat belajar memiliki hasil belajar matematika yang tinggi. 
Pada penelitiannya, Pramudhita mengungkapkan bahwa terdapat hubungan antara kebiasan mendengarkan musik dengan hasil belajar matematika.

Berdasarkan uraian yang dipaparkan, peneliti ingin mengetahui pengaruh musik pop terhadap hasil belajar siswa SMA Kelas XI pada topik Barisan dan Deret. Penelitian ini berbeda dengan penelitian yang dilakukan Pramudhita (2019) yang menggunakan materi matematika dan genre musik secara umum, dan Rosidah (2012) yang menggunakan materi matematika secara umum serta menggunakan genre musik pop dan klasik. Penelitian ini dikhususkan pada materi Barisan dan Deret, yang mana memerlukan konsentrasi dan fokus. Genre musik pada penelitian ini hanya menggunakan musik bergenre pop dan diperdengarkan pada saat proses pembelajaran.

\section{Metode}

Penelitian ini termasuk jenis eksperimen kuantitatif dengan tujuan mendeskripsikan pengaruh musik pop terhadap hasil belajar siswa SMA. Rancangan penelitian yang digunakan dalam penelitian ini adalah Post-test Only Control Design. Sampel yang digunakan terdiri dari dua kelas, diantaranya kelas kontrol dan kelas eksperimen. Kelas kontrol melaksanakan pembelajaran tanpa menggunakan musik pop sedangkan kelas eksperimen melaksanakan pembelajaran menggunakan musik pop.

Berikut gambaran desain rancangan penelitian ini (Hikmawati, 2017).

Gambar 1. Rancangan Penelitian

\begin{tabular}{|llll|}
\hline Kelas Eksperimen & $: \mathrm{R}$ & $\times$ & $\mathrm{O}_{1}$ \\
Kelas kontrol & $: \mathrm{R}$ & - & $\mathrm{O}_{2}$ \\
\hline
\end{tabular}

Keterangan:

$\mathrm{R}$ : kelompok siswa yang dipilih secara acak

$\times$ :pembelajaran diskusi menggunakan musik pop

- :pembelajaran diskusi tanpa menggunakan musik pop

$\mathrm{O}_{1} \quad$ : hasil belajar kelas eksperimen

$\mathrm{O}_{2}$ : hasil belajar kelas kontrol

Populasi pada penelitian ini merupakan seluruh siswa Kelas XI SMA Negeri 1 Pamekasan. Sampel pada penelitian ini diambil secara acak yang kemudian diperoleh kelas eksperimen yaitu kelas XI-IPA D dan kelas kontrol yaitu kelas XI-IPA E sebagai kelas kontrol. Kedua kelas diuji homogenitas sebelum dilakukan penelitan. Uji homogenitas menggunakan data nilai ulangan sebelumnya. Variabel bebas pada penelitian ini adalah pemberian musik pop. Variabel terikat pada penelitian ini adalah hasil belajar. Variabel kontrol pada penelitian ini adalah guru, metode pembelajaran, durasi pembelajaran, dan macam- macam judul lagu bergenre pop yang diputar. Musik pop yang dipilih memiliki tempo berkisar antara 90-160 bpm yang diukur menggunakan aplikasi MixMeister BPM Alayzer. Pada penelitian ini, metode tes digunakan sebagai teknik pengumpulan data. Sebelum pembelajaran, diambil nilai ulangan sebelumnya dari kedua kelas. Nilai tersebut dianalisis menggunakan uji normalitas (Kolmogorov-Smirnov) serta uji homogenitas (One-way ANOVA). Setelah pembelajaran, siswa diberi post-test. Kemudian, post-test dianalisis menggunakan uji Independent sample t-test.

\section{Hasil dan Pembahasan}

Pada penelitian ini, sampel dipilih secara acak yaitu kelas XI-IPA D dan kelas XI-IPA E. Kemudian dipilih kelas eksperimen yaitu kelas XIIPA dan kelas kontrol yaitu XI-IPA E. Kedua kelas diuji homogenitas. Uji tersebut menggunakan data nilai ulangan sebelumnya dengan jumlah soal sama dan setara. Perhatikan Tabel 1.

Tabel 1. Nilai ulangan sebelumnya

\begin{tabular}{ccc}
\hline No. & \multicolumn{2}{c}{ Nilai Ulangan sebelumnya } \\
XI-IPA D & XI-IPA E \\
\hline 1 & 68 & 86 \\
2 & 89 & 88 \\
3 & 83 & 68 \\
4 & 86 & 77 \\
5 & 66 & 71 \\
6 & 86 & 83
\end{tabular}




\begin{tabular}{|c|c|c|}
\hline 7 & 77 & 86 \\
\hline 8 & 86 & 74 \\
\hline 9 & 85 & 54 \\
\hline 10 & 77 & 74 \\
\hline 11 & 74 & 77 \\
\hline 12 & 82 & 85 \\
\hline 13 & 86 & 54 \\
\hline 14 & 82 & 65 \\
\hline 15 & 86 & 86 \\
\hline 16 & 74 & 89 \\
\hline 17 & 57 & 89 \\
\hline 18 & 83 & 89 \\
\hline 19 & 77 & 77 \\
\hline 20 & 77 & 89 \\
\hline 21 & 80 & 69 \\
\hline 22 & 80 & 74 \\
\hline 23 & 83 & 86 \\
\hline 24 & 77 & 83 \\
\hline 25 & 74 & 86 \\
\hline 26 & 77 & 83 \\
\hline 27 & 74 & 91 \\
\hline 28 & 74 & 83 \\
\hline 29 & 91 & 72 \\
\hline 30 & 65 & 80 \\
\hline 31 & 74 & 83 \\
\hline 32 & 83 & 80 \\
\hline 33 & 80 & 80 \\
\hline 34 & 86 & 83 \\
\hline Total Nilai & 2679 & 2694 \\
\hline Rata-rata & 78,79 & 79,23 \\
\hline
\end{tabular}

Pada penelitian ini terdapat dua pertemuan. Pada pertemuan pertama kedua kelas diberikan materi awal dan siswa diminta mendiskusikan soalsoal secara berkelompok. Pada kelas eksperimen diperdengarkan lagu pop ketika diskusi berlangsung sedangkan kelas kontrol tidak diperdengarkan lagu pop. Pada pertemuan kedua siswa kembali mendiskusikan materi selama satu jam pelajaran kemudian dilanjutkan dengan tes hasil belajar selama 30 menit. Siswa mengerjakan tes hasil belajar sebanyak lima soal uraian. Pada kelas eksperimen siswa diperdengarkan musik selama tes berlangsung sedangkan kelas kontrol tidak diperdengarkan musik.

Pada pertemuan pertama terdapat seorang siswa yang tidak masuk pada kelas eksperimen. Pada pertemuan kedua terdapat dua orang siswa tidak masuk pada kelas eksperimen dan tiga orang siswa tidak masuk pada kelas kontrol. Sehingga pada penelitian ini menggunakan total 62 orang siswa dengan masing-masing kelas 31 siswa. Setelah melakukan tes hasil belajar maka diperoleh nilai post-test. Perhatikan Tabel 2.

Tabel 2. Nilai Post-test

\begin{tabular}{|c|c|c|}
\hline \multirow{2}{*}{ No. } & \multicolumn{2}{|c|}{ Nilai } \\
\hline & XI-IPA D & XI-IPA E \\
\hline 1 & 90 & 88 \\
\hline 2 & 35 & 52 \\
\hline 3 & 95 & 63 \\
\hline 4 & 57 & 83 \\
\hline 5 & 94 & 80 \\
\hline 6 & 88 & 93 \\
\hline 7 & 95 & 88 \\
\hline 8 & 88 & 92 \\
\hline 9 & 92 & 90 \\
\hline 10 & 85 & 73 \\
\hline 11 & 95 & 60 \\
\hline 12 & 75 & 80 \\
\hline 13 & 87 & 33 \\
\hline 14 & 95 & 91 \\
\hline
\end{tabular}




\begin{tabular}{ccc}
15 & 98 & 73 \\
16 & 95 & 96 \\
17 & 95 & 92 \\
18 & 83 & 87 \\
19 & 88 & 58 \\
20 & 89 & 67 \\
21 & 95 & 49 \\
22 & 79 & 80 \\
23 & 94 & 90 \\
24 & 49 & 57 \\
25 & 70 & 54 \\
26 & 83 & 92 \\
27 & 94 & 95 \\
28 & 97 & 97 \\
29 & 78 & 51 \\
30 & 96 & 63 \\
31 & 69 & 97 \\
\hline Total Nilai & $\mathbf{2 6 2 3}$ & $\mathbf{2 3 6 4}$ \\
Rata-rata & $\mathbf{8 4 , 6 1}$ & $\mathbf{7 6 , 1 6}$ \\
\hline
\end{tabular}

Uji Homogenitas

Pada peneltian ini menggunakan One way Annova untuk uji homogenitas dengan bantuan aplikasi SPSS. Uji homogenitas digunakan untuk membuktikan bahwa kedua kelas yang dipilih merupakan kelas yang homogen. Data yang dianalisis adalah nilai ulangan sebelumnya. Perhatikan Tabel 3:

$\mathrm{H}_{0}$ : kedua kelas homogen

$\mathrm{H}_{1}$ : kedua kelas tidak homogen

Tabel 3. Hasil Uji Homogenitas

\begin{tabular}{cccc}
\hline $\begin{array}{c}\text { Levence } \\
\text { Statistic }\end{array}$ & df1. & df2. & Sig. \\
\hline 1.455 & 1 & 66 & .232 \\
\hline
\end{tabular}

Berdasarkan Tabel 3, diperoleh nilai Sig sebesar 0,232. Hal itu mengakibatkan $\mathrm{H}_{0}$ diterima serta $\mathrm{H}_{1}$ ditolak. Sehingga diperoleh kesimpulan bahwa kedua kelas homogen.

Uji Normalitas
Pada penelitian ini menggunakan Kolmogorov Smirnov untuk uji normalitas dengan bantuan aplikasi SPSS. Perhatikan Tabel 4:

$\mathrm{H}_{0}$ : data berdistribusi normal

$\mathrm{H}_{1}$ : data tidak berdistribusi normal

Tabel 4. Hasil Uji Normalitas

\begin{tabular}{llr}
\hline & & $\begin{array}{c}\text { Unstandardized } \\
\text { Residual }\end{array}$ \\
\hline $\mathrm{N}$ & & 34 \\
Normal Parameter & Mean & .0000000 \\
& Std. Deviation & 8.88707254 \\
Most Extreme Differences & Absolute & .143 \\
& Positive & .077 \\
& Negatif & -.143 \\
Kolmogorov-Smirnov Z & & .834 \\
Asymp. Sig. (2-tailed) & & .489 \\
\hline
\end{tabular}

Berdasarkan Tabel 4, diketahui nilai Asymp. Sig (2-tailed) sebesar 0,489. Hal itu mengakibatkan H0 diterima dan H1 ditolak. Sehingga diperoleh kesimpulan bahwa data berdistribusi normal. Uji-t

Uji-t pada penelitian ini menggunakan Independent sample t-test dibantu dengan aplikasi SPSS. Uji-t memiliki tujuan untuk mengetahui pengaruh musik pop secara signifikan terhadap hasil belajar siswa. Perhatikan Tabel 5:

$\mathrm{H}_{0}$ : Tidak terdapat perbedaan signifikan pada kedua kelas

$\mathrm{H}_{1}$ : Terdapat perbedaan signifikan pada kedua kelas 
Tabel 5. Hasil Uji Independent Sample T-Test

\begin{tabular}{lccccrr}
\hline & \multicolumn{5}{c}{$\begin{array}{c}\text { Levene's Test } \\
\text { for Equality of } \\
\text { Variances }\end{array}$} \\
\hline & \multicolumn{1}{c}{ F } & Sig. & \multicolumn{1}{c}{ t } & df & Sig.(2-tailed) \\
\hline Hasil belajar matematika & $\begin{array}{c}\text { Equal variances } \\
\text { assumed } \\
\text { Equeal variances } \\
\text { not assumed }\end{array}$ & 3.478 & .067 & 2.025 & 60 & .047 \\
& & & 2.025 & 58.37 & .047 \\
\hline
\end{tabular}

Berdasarkan Tabel 5, diperoleh nilai Sig (2tailed) sebesar 0,047. Hal itu mengakibatkan H0 ditolak serta H1 diterima. Sehingga dapat disimpulkan bahwa musik pop memiliki pengaruh yang signifikan terhadap hasil belajar. Kemudian akan dilihat kelas manakah yang lebih baik. Perhatikan tabel 6.

Tabel 6. Lanjutan Hasil Uji-t

\begin{tabular}{|c|c|c|c|c|c|}
\hline & Kelas & $\mathbf{N}$ & Mean & $\begin{array}{l}\text { Std. } \\
\text { Deviation }\end{array}$ & $\begin{array}{l}\text { Std. Error } \\
\text { Mean }\end{array}$ \\
\hline \multirow[t]{2}{*}{ Hasil Belajar Matematika } & Kelas Musik & 31 & 84.6129 & 14.99706 & 2.69355 \\
\hline & Kelas Tanpa Musik & 31 & 76.1613 & 17.74654 & 3.18737 \\
\hline
\end{tabular}

Pada Tabel 6, kelas XI-IPA D memiliki nilai rata-rata sebesar 84,61 sedangkan kelas XI-IPA E memiliki nilai rata-rata sebesar 76,16. Kelas eksperimen memiliki nilai rata-rata yang lebih tinggi dibandingakn dengan kelas kontrol dengan selisih nilai rata-rata kedua kelas sebesar 8,45. Berdasarkan data tersebut, dapat disimpulkan bahwa musik pop memiliki pengaruh secara positif terhadap hasil belajar siswa.

Hasil yang diperoleh dari penelitian ini sesuai dengan yang diungkapkan Natalia (2017) bahwa musik dapat menstimulasi kinerja otak seseorang. Selain itu, irama musik juga mempengaruhi kerja otak. Irama yang kuat akan meningkatkan konsentrasi sedangkan irama yang lambat akan meningkatkan fokus. Namun, apabila irama musik yang didengar terlalu kuat ataupun terlalu pelan, seseorang akan terganggu kinerjanya (Gremonia, 2014).

Hasil yang diperoleh dari penelitian ini juga sesuai dengan penelitian terdahlu. Fika (2008) mengungkapkan musik musik memiliki pengaruh terhadap hasil belajar siswa. Pada penelitian tersebut siswa yang mendengarkan musik pop pada saat pembelajaran berlangsung, hasil belajar yang diperoleh lebih tinggi apabila dibandingkan dengan hasil belajar siswa yang mendengarkan musik klasik dan siswa yang tidak mendengarkan musik. Pada penelitan Sarosa (2002) tentang pengaruh musik pop Indonesia terhadap prestasi belajar matematika SLTP Kelas I mengungkapkan hal serupa. Prestasi belajar siswa yang mendengarkan musik pop lebih baik sebesar $38,8 \%$ apabila dibandingkan dengan siswa yang tidak mendengarkan musik pop. Hasil tersebut menandakan bahwa musik pop lebih efektif apabila diterapkan dalam pembelajaran matematika.

\section{Simpulan}

Musik pop memiliki pengaruh signifikan terhadap hasil belajar. Hasil ini dapat diketahui dari pengujian statistik menggunakan aplikasi SPSS. Nilai Sig (2-tailed) yang didapat sebesar 0,047 dimana kurang dari 0,05. Kemudian akan dilihat selisih nilai rata-rata hasil belajar kelas kontrol dan eksperimen. Hal ini dilakukan untuk mengetahui musik pop berpengaruh positif atau tidak.

Rata-rata nilai ulangan harian sebelum pembelajaran di kelas kontrol adalah 79,23 sedangkan rata-rata nilai ulangan harian sebelum pembelajaran di kelas eksperimen adalah 78,79. Kelas kontrol dan kelas eksperimen memiliki selisih nilai rata-rata sebesar 0,44 . Selisih rata-rata nilai ulangan harian sebelum pembelajaran cukup berbeda dengan selisih rata-rata nilai ulangan setelah pembelajaran dilakukan. Rata-rata nilai post test di kelas kontrol adalah 76,16 sedangkan rata-rata nilai post-test pada kelas eksperimen adalah 84,61. Kelas eksperimen dan kelas kontrol memiliki selisih nilai rata-rata post-test sebesar 8,45 . Berdasarkan data tersebut, dapat disimpukan bahwa musik pop berpengaruh positif terhadap hasil belajar siswa.

Hasil yang diperoleh pada penelitian ini, menjunjukkan bahwa terdapat peningkatan hasil belajar dari pembelajaran menggunakan musik pop pada materi barisan dan deret. Hal tersebut dapat menjadi alternatif dalam melaksanakan pembelajaran agar siswa tidak bosan dalam kegiatan belajar di sekolah. 


\section{Daftar Pustaka}

Aritonang, Keke. 2008. "Minat dan Motivasi dalam Meningkatkan Hasil Belajar Siswa." Jurnal Pendidikan Penabur 11-21.

Chou, Ming, and Peter Tze. 2010. "Attention drainage effect: How background music effects concentration in Taiwanese college students ." Journal of the Scholarship of Teaching and Learning 36-46.

Fika, Ariani. 2008. Pengaruh Musik dan Intelegensi Visual Spasial Terhadap Hasil Belajar Matematika Siswa Kelas V Kompleks SD Jalan Halat Medan. Medan: UNIMED.

Grimonia, Eya. 2014. Dunia Musik (Sains-Musik Untuk Kebaikan Hidup). Bandung: NUANSA CENDEKIA.

Hikmawati, Fenti. 2017. METODOLOGI PENELITIAN. Depok: RajaGrafindo Persada.

Kemendikbud. 2019. Pusat Penilaian Pendidikan Kementrian Pendidikan dan Kebudayaan. Accessed September 25, 2019. http://puspendik.kemdikbud.go.id/hasil-un/.

Natalia, Dian. 2013. Terapi Musik Bidang Keperawatan. Jakarta: Mitra Wacana Media.

Pramudhita, Ria, Chatarina. 2019. "HUBUNGAN KEBIASAAN MENDENGARKAN MUSIK, PEMANFAATANNYA SAAT BELAJAR MATEMATIKA TERHADAP HASIL BELAJAR MATA PELAJARAN MATEMATIKA SISWA KELAS XI DI SMK PIKA SEMARANG." Digilib UNNES.

Prasetya, Indra , Tri. 2012. "Meningkatkan Keterampilan Menyusun Instrumen Hasil
Belajar Berbasis Modul Interaktif Bagi Guruguru IPA SMPN Kota Magelang." Journal of Educational Research and Evaluation 106112.

Ricardo. 2017. "Impak minat dan motivasi belajar terhadap hasil belajar siswa ." JURNAL PENDIDIKAN MANAJEMEN PERKANTORAN 79-92.

Rosidah, Cholifatur. 2012. "Pengaruh musik klasik dan musik pop terhadap kinerja peserta tes matematika: Studi eksperimen kelas $\mathrm{X}$ di MAN Mojosari-Mojokerto." Electronic Theses.

Salim, Danny. 2010. "Pengaruh Musik Terhadap Konsentrasi Belajar Siswa Kelas 12 SMUK Salatiga." Jurnal Musik 23-32.

Sarosa, Aradea. 2002. "Pengaruh musik pop Indonesia terhadap prestasi belajar matematika siswa SLTP kelas I." Repository Universitas Sanata Dharma Yogyakarta.

Silalahi, Marina. 2017. Konsumsi Media Gen Z. Accessed Januari 6, 2020. https://mix.co.id/marcomm/newstrend/konsumsi-media-gen-z/.

Silverius, Suke. 1991. Evaluasi Belajar dan Umpan Balik. Jakarta: PT Grasindo.

Sumargiyani, and Iqna, Muhammad Hibatallah. 2018. "Analisis Kemampuan Pemecahan Masalah Siswa pada Materi Barisan dan Deret Siswa Kelas XI IPA MA Ali Maksum." Prosiding Seminar Nasional Etnomatnesia 891-900.

Taher, Dahlan. 2009. Sejarah musik 2. Yogyakarta: Universitas Negeri Yogyakarta. 